PNL-2481

UC-70

\title{
Development of Glass \\ Formulations Containing High-Level Nuclear Wastes
}

by

Wayne A. Ross

February 1978

Prepared for the U.S. Department of Energy under Contract EY-76-C-06-1830 
This report was prepared as an account of work sponsored by the United States Government. Neither the United States nor the Department of Energy, nor any of their tmployees, nor any of theit contraciors, iubcontractors, or their employees, makes any warranty, express or implied, or assumes any legal Hability or responsibility for the accuracy, completeness or usefulness of any information, apparatus, prociuct or process disclosed, or represents that its use would not infringe privately owned rights.

The views, opinions and conclusions contained in this report are those of the contractor and do nor necessarily represent those of the United States Government or the United States Department of Energy.

PACIFIC NORTHWEST LABCRATORY

operated by

BATTELLE

for the

UNITED STATES DEPARTMENT OF ENERCY

Under Contract EY-76-C-06-1830

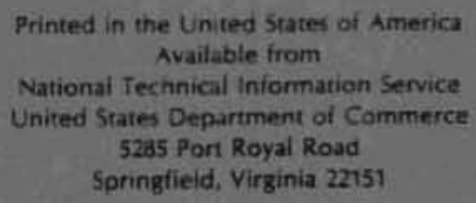

Price: Printed Copy 2 - Microfiche 53.00

\begin{tabular}{c|c} 
& NTIS \\
-Pages & Seling Price \\
$007-025$ & 51.50 \\
$026-050$ & 55.00 \\
$051-075$ & 55.50 \\
$076-100$ & 56.00 \\
$101-125$ & 56.50 \\
$726-150$ & 57.00 \\
$751-175$ & 57.75 \\
$176-200$ & 58.50 \\
$201-225$ & 58.75 \\
$226-250$ & 59.00 \\
$257-275$ & 510.00 \\
$276-300$ & 570.25 \\
&
\end{tabular}


$P N L=2481$

33679000490997

UC-70

DEVELOPMENT OF GLASS FORMULATIONS

CONTAINING HIGH-LEVEL NUCLEAR WASTES

by

Wayne A. Ross

February 1978

BATTELLE

Pacific Northwest Laboratories

Richland, Washington 99352 


\section{CONTENTS}

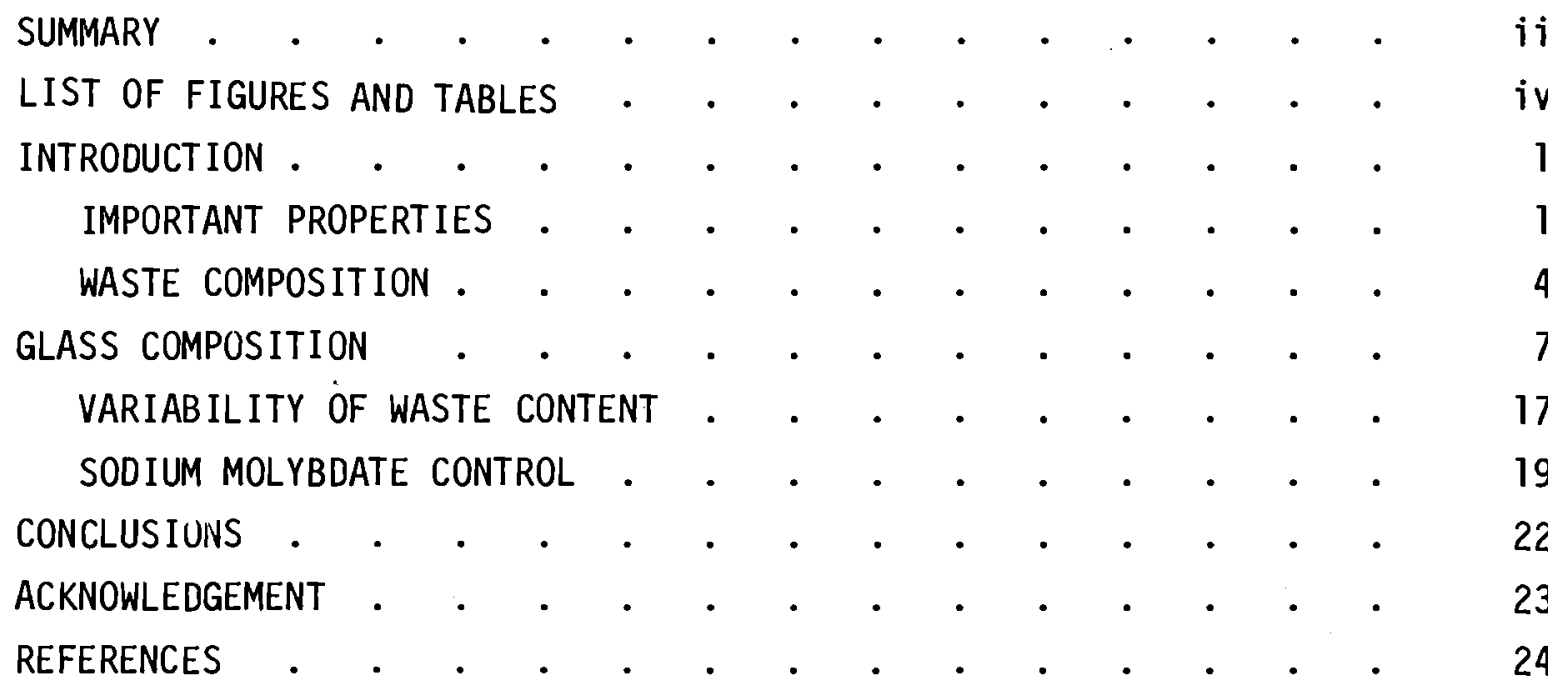




\section{SUMMARY}

The effects of $\mathrm{Na}_{2} \mathrm{O}, \mathrm{K}_{2} \mathrm{O}, \mathrm{B}_{2} \mathrm{O}_{3}, \mathrm{TiO}_{2}, \mathrm{CaO}$, and $\mathrm{ZnO}$ contents were determined on the leach rate and homogeneity of a potential high-level waste glass. It was found that the two characteristics are in competition, with variations of $\mathrm{CaO}$ having the greatest effect and $\mathrm{TiO}_{2}$ having the least effect.

Boron oxide content is important in control of $\mathrm{Na}_{2} \mathrm{MoO}_{4}$ formation and separation. Sodium molybdate formation can also be controlled by the use of reducing agents.

The waste glass discussed in this report can tolerate from $0-50 \%$ waste content with minor effects on leachability and viscosity. 


\section{LIST OF FIGURES}

1 Task Relationships . . . . . . . . . . . . . . 3

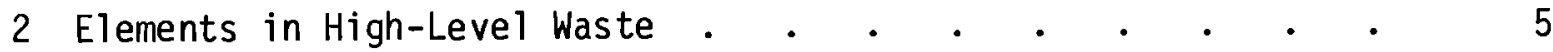

3 Leachability of 76-375 Type Glass with Change in $\mathrm{Na}_{2} \mathrm{O}$ Content $. \quad . \quad . \quad . \quad . \quad . \quad . \quad . \quad . \quad . \quad 10$

4 Leachability of 76-375 Type Glass with Change in $\mathrm{K}_{2} \mathrm{O}$ Content . . . . . . . . . . . . . . 11

5 Leachability of 76-375 Type Glass with Change in $\mathrm{B}_{2} \mathrm{O}_{3}$ Content . . . . . . . . . . . 12

6 Leachability of 76-375 Type Glass with

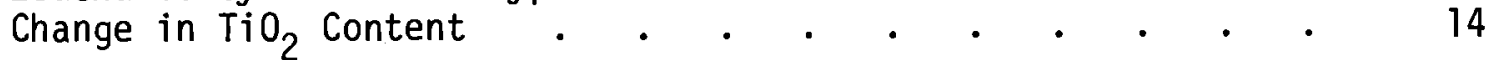

7 Leachability of 76-375 Type Glass with Change in CaO Content. . . . . . . . . .

8 Leachability of 76-375 Type Glass with Change in ZnO Content . . . . . . . . . . . . . . 16

9 Effect of Waste Content on Viscosity at $1050^{\circ} \mathrm{C}$ and Acid Leachability as a Function of Waste Oxide Content . . . . 18

10 Comparison of Engineering Scale Canisters Showing the Improvement in Homogeneity with Use of Reducing Agents

\section{LIST OF TABLES}

1 Composition of PW-4b-1 Simulated High-Level Waste . . . . 6

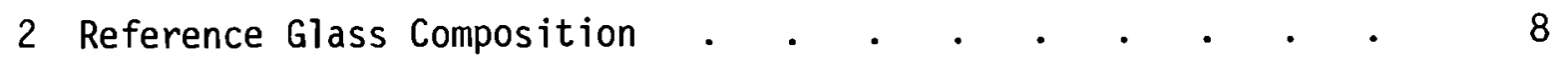




\section{INTRODUCTION}

The incorporation of high-level radioactive wastes into a glass structure or matrix has been long recognized as an attractive method for handling these wastes and preparing them for disposal. Many of the attractive features which make glass the current choice as a waste form were recently reviewed. ${ }^{(1)}$ Work on glass formulations has been carried out both in this country (2-4) and abroad ${ }^{(5-7)}$ for many years. During the early development phosphate glasses were utilized, however, most of the recent formulations have been based on borosilicate type compositions.

Since high level wastes vary widely in composition due to different process conditions and fuel types, various glass compositions are optimum for each waste and process. The results of this study apply to a high level waste (PW-4b) and are based on the properties discussed below.

\section{IMPORTANT PROPERTIES}

The ultimate objective of waste solidification is to prevent significant release of radiation and radioactive materials to the environment. The most likely method is through contact of the waste with water, with subsequent leaching of radioisotopes, and migration into the environment. The leachability of waste forms is therefore a major concern. Long-term stability of the glasses with regard to thermal and radiation effects is al so necessary to maintain the desired low leachability of the waste form. These effects are discussed in more detail in a separate report. ${ }^{(8)}$ To obtain a consistent product with the desired properties, homogeneity of the waste glasses is 
important, though the degree of homogeneity required is much less than that of commercial glasses.

The processing equipment and allowable process conditions must also be carefully considered in developing glass formulations. Two melting systems, the ceramic melter and the in-can melter have been developed, each with its own set of specific requirements. $(9,10)$ The ceramic melter originally selected for this development requires that the melts be oxidized (i.e., no reducing agents can be used) and that maximum melting temperature be limited to $1150^{\circ} \mathrm{C}$. At this temperature the viscosity of the glass must be below 200 poise to allow refining of the glass melt. At temperatures greater than $1150^{\circ} \mathrm{C}$ the volatility of $\mathrm{Cs}_{2} \mathrm{O}$ and corrosion of the electrodes become a concern.

Since long periods of time are required to determine glass behavior under thermal and radiation conditions, the glass development has proceeded under the two-step plan shown in Figure 1. Development undergoes two iterative loops, beginning with numerous iterations around the inner loop, with optimization based on leachability, viscosity, and homogeneity. The optimal glass from this loop is then subjected to a much more detailed test plan. (11) This report will be confined to a specific set of experiments in the inner melt formulation loop. 


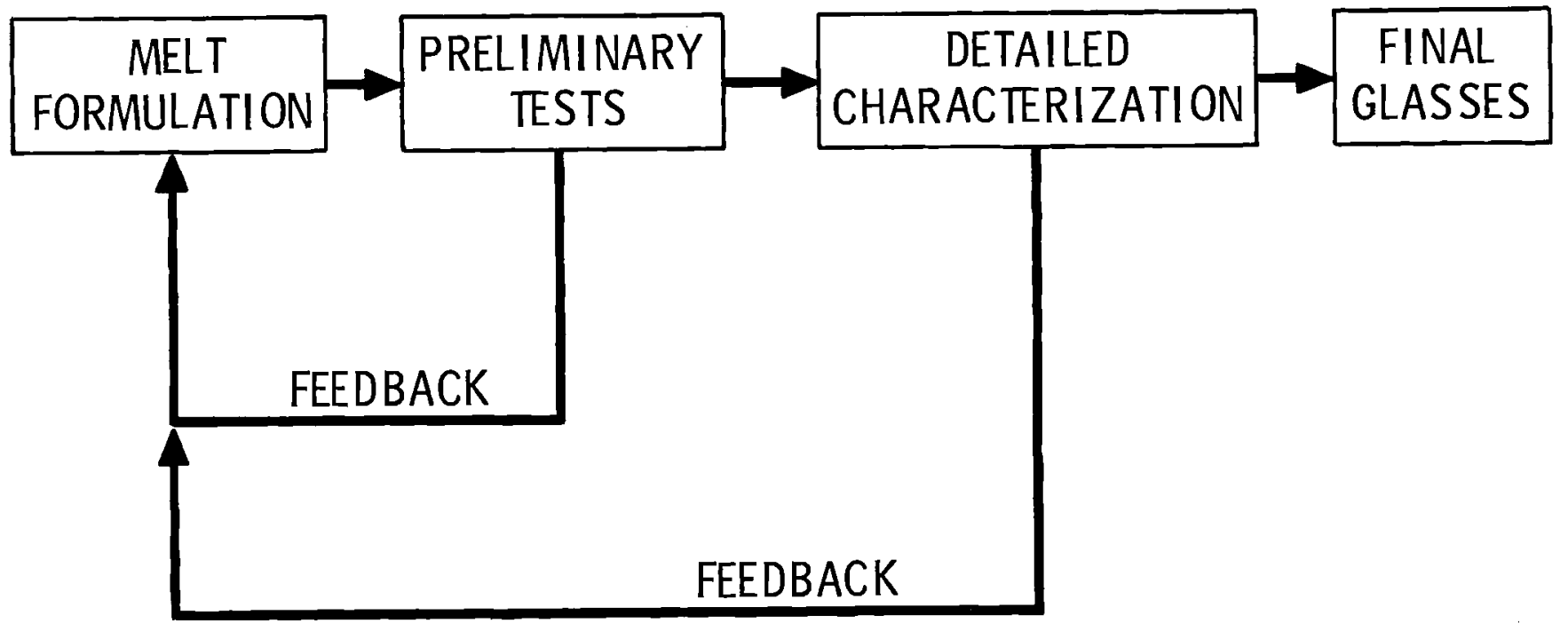

FIGURE 1. Task Relationships 


\section{WASTE COMPOSITION}

As shown in Figure 2 high-level waste is composed of elements from three sources: fission products, actinides and process chemicals. Fission products are produced from burnup of the fuel in reactor and represent over $99 \%$ of the radioactivity in al1 nuclear wastes; actinides result from neutron capture and uranium and plutonium that have not been completely removed during solvent extraction in the reprocessing plant, (typically 0.1 to $1.0 \mathrm{wt} \%$ ); and process chemicals are added during reprocessing. Examples are gadolinium for criticality control and addition of the intermediate level waste stream from cleanup of the solvent extraction solutions, which add sodium and phosphate. The concentrations and types of inerts vary with each reprocessor. The simulated composition used for our series of tests is called PW-4b-1 (shown in Table 1), a very clean waste with low inerts and low uranium and plutonium content. The PW-4b-1 compcsition contain chemical substitutions for radioisotopes in $\mathrm{PW}-4 \mathrm{~b}$. The referenced $\mathrm{PW}-4 \mathrm{~b}$ composition and other simulations are detailed in Table 2 of Reference 8. 


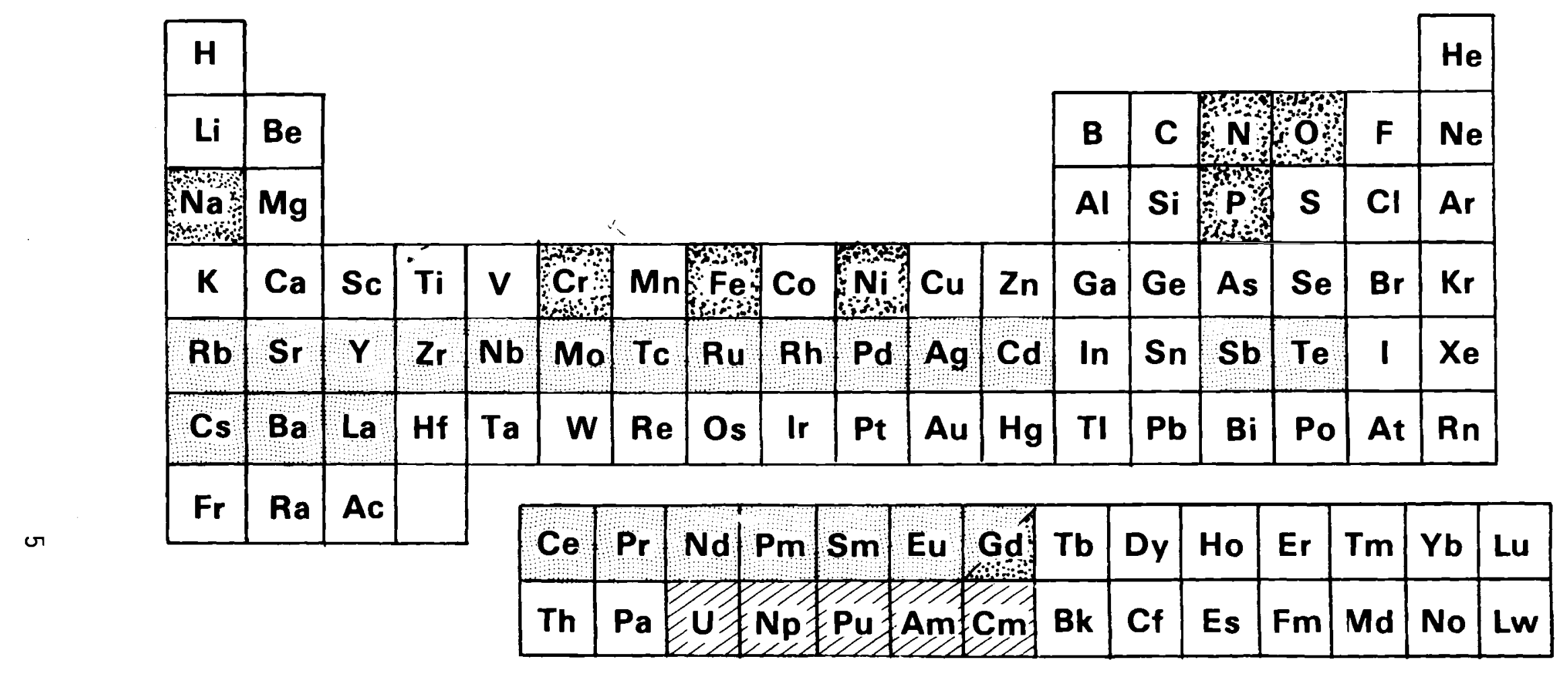

PRINCIPAL FISSION PRODUCTS

ACTINIDES

REPROCESSING CHEMICALS

FIGURE 2. Elements in High-Level Waste 
TABLE 1. Composition of PW-4b-1 Simulated High-Level Waste

\begin{tabular}{|c|c|}
\hline Oxide & $w t / 0$ \\
\hline $\mathrm{Fe}_{2} \mathrm{O}_{3}$ & 8.40 \\
\hline $\mathrm{Cr}_{2} \mathrm{O}_{3}$ & 0.88 \\
\hline $\mathrm{NiO}$ & 2.68 \\
\hline $\mathrm{P}_{2} \mathrm{O}_{5}$ & 1.71 \\
\hline $\mathrm{Rb}_{2} \mathrm{O}$ & 0.90 \\
\hline sro & 2.70 \\
\hline $\mathrm{Y}_{2} \mathrm{O}_{3}$ & 0.07 \\
\hline $\mathrm{ZrO}_{2}$ & 12.61 \\
\hline $\mathrm{MoO}_{3}$ & 16.26 \\
\hline $100^{\circ}$ & 0.78 \\
\hline $\mathrm{Ag}_{2} \mathrm{O}$ & 0.22 \\
\hline $\mathrm{Cd} 0$ & 0.25 \\
\hline $\mathrm{TeO}_{2}$ & 1.85 \\
\hline $\mathrm{Cs}_{2} 0$ & 7.35 \\
\hline $\mathrm{BaO}$ & 4.00 \\
\hline $\mathrm{La}_{2} \mathrm{O}_{3}$ & 8.20 \\
\hline $\mathrm{CeO}_{2}$ & 16.39 \\
\hline $\operatorname{Pr}_{6}{ }^{0} 11$ & 1.71 \\
\hline $\mathrm{Nd}_{2} \mathrm{O}_{3}$ & 5.81 \\
\hline $\mathrm{Sm}_{2} \mathrm{O}_{3}$ & 1.03 \\
\hline $\mathrm{Eu}_{2} \mathrm{O}_{3}$ & 0.27 \\
\hline $\mathrm{Gd}_{2} \mathrm{O}_{3}$ & 0.68 \\
\hline $\mathrm{U}_{3} \mathrm{O}_{8}$ & 5.30 \\
\hline & 00.05 \\
\hline
\end{tabular}




\section{GLASS COMPOSITION}

After a series of scouting tests, a tentative glass composition was chosen for the PW-4b-1 waste, the principal criteria were high chemical durability over the $\mathrm{pH} 4$ to 9 range, oxidizing melting conditions, and maximum melting temperature of $1150^{\circ} \mathrm{C}$. This composition (76-375) is shown in Table 2. Note that the glass is a borosilicate with quite high mixed alkali and minor additions of $\mathrm{ZnO}$ and $\mathrm{TiO}_{2}$; the $1 / 3$ waste addition adds considerable $\mathrm{ZrO}_{2}$, rare earth (RE) oxides and $\mathrm{Fe}_{2} \mathrm{O}_{3}$, which generally increase glass durability. The effects of the high concentration of $\mathrm{MoO}_{3}$ shown in the table will be discussed later. The waste added to a glass is chosen to minimize the total volume.

To verify that the composition for the glass frit was appropriate, a series of melt tests was performed to observe homogeneity and leach rates. For each test a component oxide concentration of the frit was varied by replacing or being replaced by an equal weight percent of silica. These samples were prepared as 40 gram melts by blending a simulated waste and the raw glass components with mortar and pestle and then heating at $1150^{\circ} \mathrm{C}$ for 2 hours in platinum crucibles. The glass was air quenched, then photographed and ground to $-40+60$ mesh for a consecutive series of leach tests. The first leach test was performed in room-temperature $\mathrm{NH}_{4} \mathrm{OH}-\mathrm{NH}_{4} \mathrm{Cl}$ solution buffered to $\mathrm{pH}$ 9, the second in room-temperature sodium acetate-acetic acid solution buffered to $\mathrm{pH} 3.9$, and the third (Soxhlet test) used distilled water at $99^{\circ} \mathrm{C}$. Each leach test was for a 24-hr period. Each sample was contained in a 200-mesh stainless steel envelope, with leach rates determined from weight loss. More details on leach testing are included in another publication. 
TABLE 2. Reference Glass Composition (76-375)

\begin{tabular}{|c|c|}
\hline Glass Frit & $\mathrm{Wt} \%$ \\
\hline $\mathrm{SiO}_{2}$ & 35 \\
\hline $\mathrm{B}_{2} \mathrm{O}_{3}$ & 13 \\
\hline $\mathrm{CaO}$ & 2 \\
\hline $\mathrm{ZnO}$ & 5 \\
\hline $\mathrm{TiO}_{2}$ & 3 \\
\hline $\mathrm{Na}_{2} \mathrm{O}$ & 5 \\
\hline $\mathrm{K}_{2} \mathrm{O}$ & 4 \\
\hline Subtotal & 67 \\
\hline Waste Additions (PW-4b-1) & 33 \\
\hline Total & 100 \\
\hline
\end{tabular}


The results of tests on the effects of $\mathrm{Na}_{2} \mathrm{O}$ content are shown in Figure 3 , which also identifies the nominal composition of the standard 76-375 melt. Additions of $\mathrm{Na}_{2} \mathrm{O}$ above that of the standard composition further increases the homogeneity of the glass and also increases leachability as measured by all three methods. It is also interesting to note that leach rates were actually decreased by the addition of $\mathrm{Na}_{2} \mathrm{O}$ at low levels. As might be anticipated, alkali content must be maintained at moderately high levels to allow melting at the relatively low processing temperatures. Potassium oxide effects, shown in Figure 4, are similar to $\mathrm{Na}_{2} \mathrm{O}$; however, the changes seem to be more significant on a per mole basis. The changes shown are at 2 wt\% intervals versus the previous 1 wt\%, but on a mole basis, they are very similar. Potassium oxide is used both to take advantage of the "mixed alkali" effects on viscosity and also to retard liquid phase separation, common with borosilicates.

Boron oxide is utilized in waste glasses, both to lower viscosity and enhance homogeneity (Figure 5). The 7 wt\% melt has several surface phases; one is a yellow phase (Figure 5) around the edge of the melt (sodium molybdate), which is particularly troublesome. It is undesirable both because it is water soluble and also because it contains significant amounts of cesium and strontium--the two most hazardous elements during the early life of the waste. The addition of increased amounts of $\mathrm{B}_{2} \mathrm{O}_{3}$ is one method of increasing the solubility of the molybdate in the glass. An additional method will be discussed later. The leachability decreases in the $\mathrm{pH} 9$ solutions, with $\mathrm{B}_{2} \mathrm{O}_{3}$ increasing from 7 to $11 \%$. This is due primarily to the 

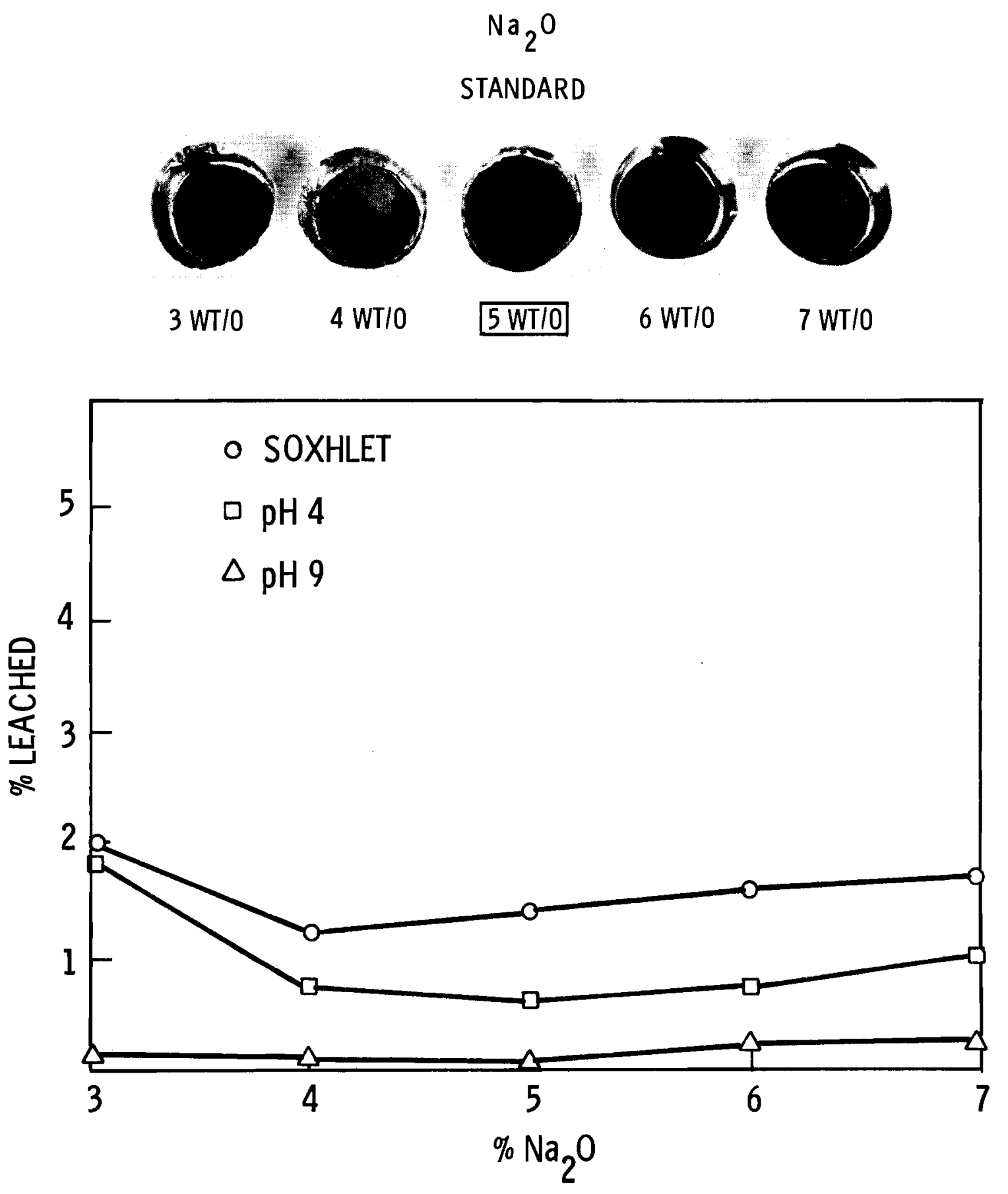

FIGURE 3. Leachability of 76-375 Type Glass with Change in $\mathrm{Na}_{2} \mathrm{O}$ Content 


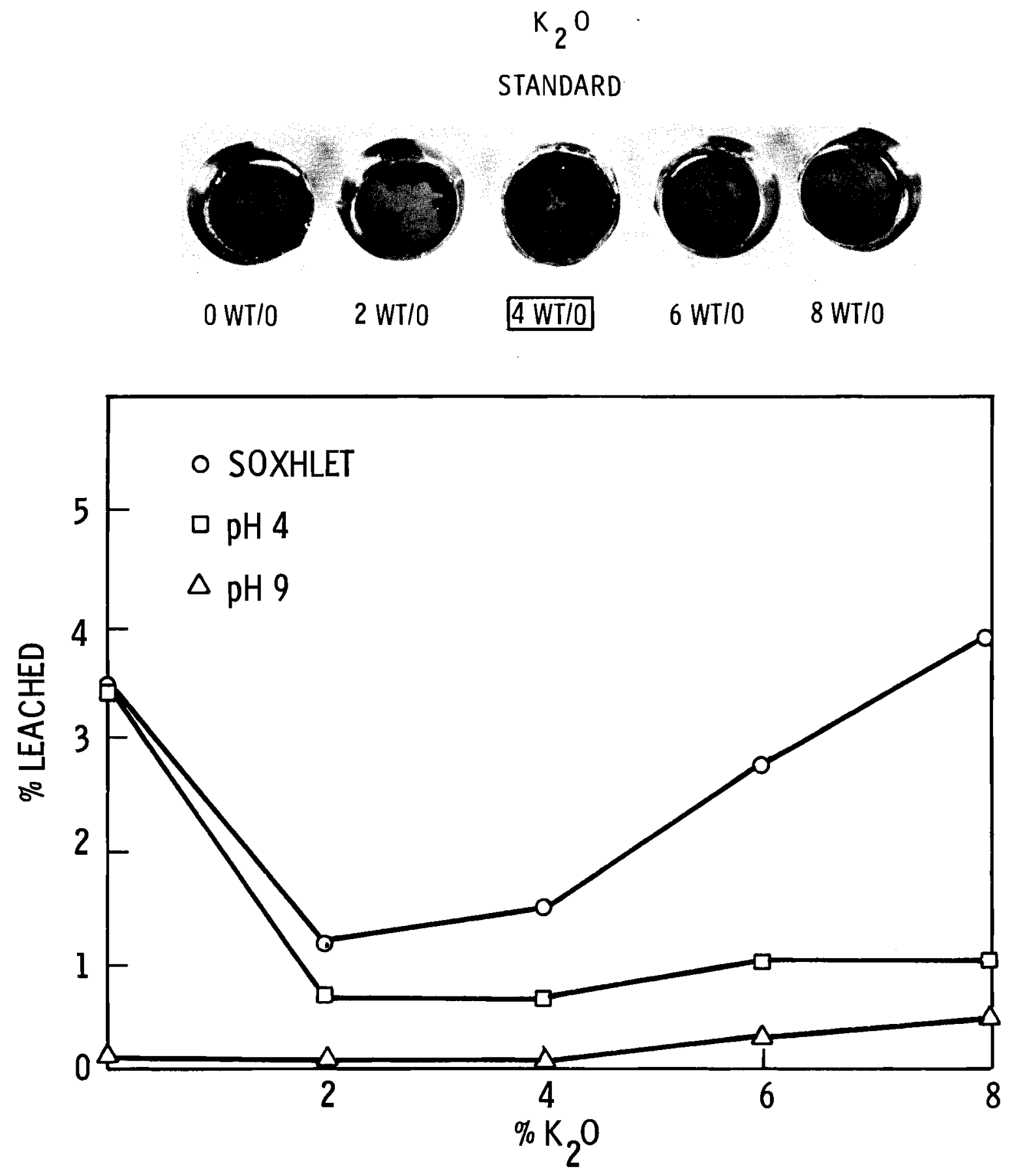

FIGURE 4. Leachability of 76-375 Type Glass with Change in $\mathrm{K}_{2} \mathrm{O}$ Content 


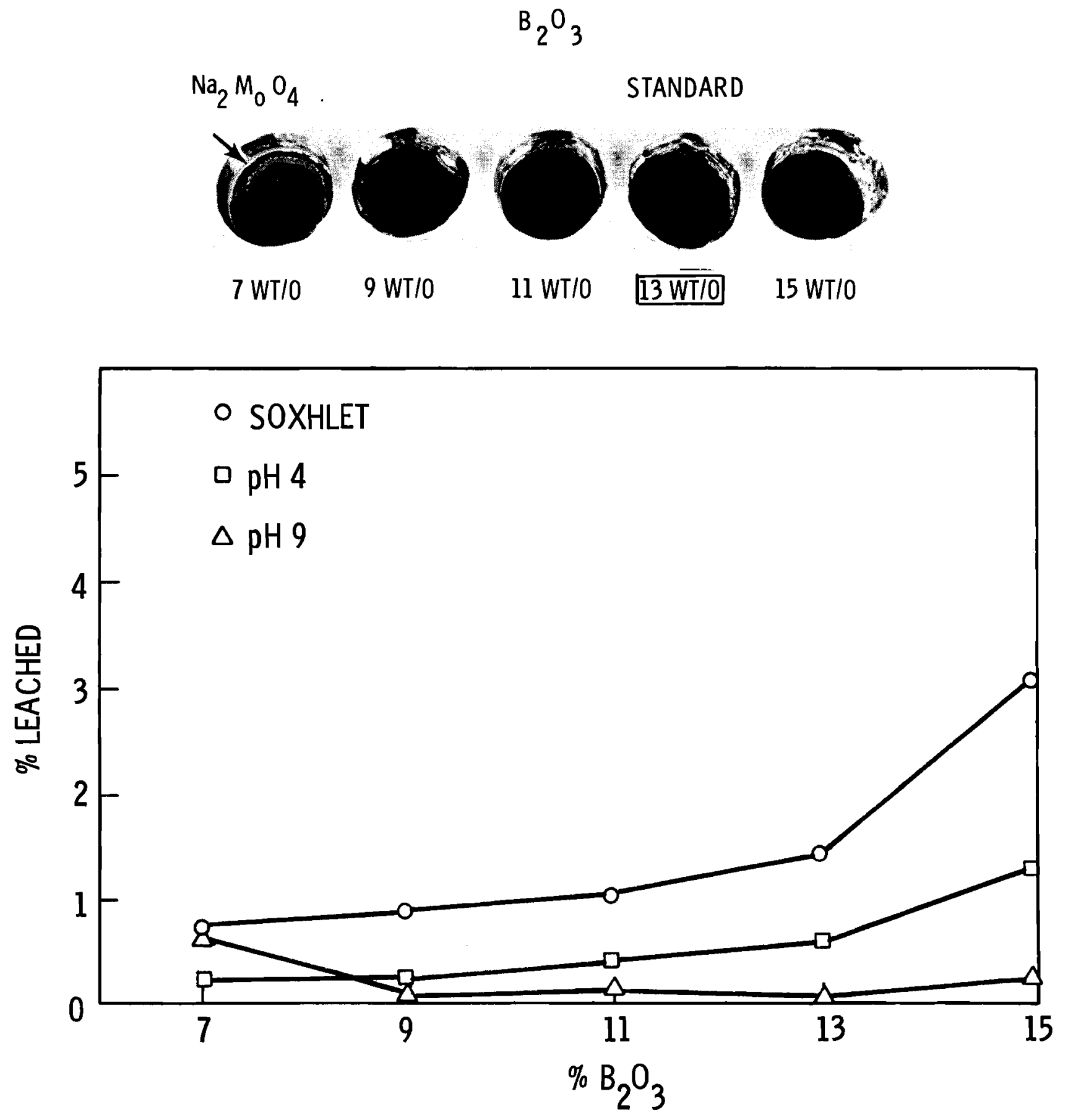

FIGURE 5. Leachability of 76-375 Type Glass with Change in $\mathrm{B}_{2} \mathrm{O}_{3}$ Content 
el imination of the molybdate phase. Since $\mathrm{B}_{2} \mathrm{O}_{3}$ increases bulk leaching, slightly lower concentrations would be desirable if adequate homogeneity could be obtained.

Homogeneity and leachability comparisons of glasses containing $\mathrm{TiO}_{2}$ are shown in Figure 6. Small additions of $\mathrm{TiO}_{2}$ appear beneficial in lowering viscosity and also leachability. Large concentrations of titania can be expected to increase devitrification potentials and therefore need to be limited. The effects of $\mathrm{TiO}_{2}$ on glass homogeneity appear to be minor. The standard was melted in a different batch, which may account for its slight decrease in homogeneity in comparison to the other samples.

Calcium oxide has major effects in waste glasses, as can be seen in Figure 7. This is a classic case of trade offs between homogeneity (which is greatly improved by calcia additions) and leachability, which also greatly increases with calcia. The acid durability is particularly affected, with a very rapid increase beyond $4 \mathrm{wt} \% \mathrm{CaO}$. The $2 \% \mathrm{CaO}$ used represents a balance between the two conflicting requirements.

Zinc oxide has been used quite extensively in waste glasses, with some previous compositions containing as much as $21 \mathrm{wt} \% \mathrm{ZnO}$. Much smaller amounts are now used because of the rapid increase in acid attack with increasing Zno content (indicated in Figure 8). Leachability (as measured by the 
$\mathrm{TiO}_{2}$

STANDARD
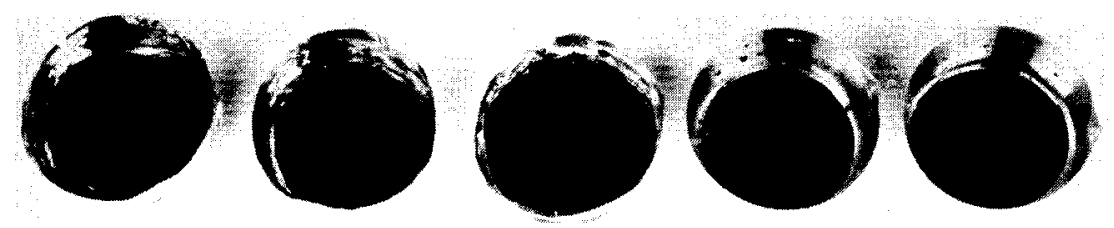

$0 \mathrm{WT} / 0$

$1.5 \mathrm{WT} / 0$

3 WT/0

4.5 WT/0 6 WT/0

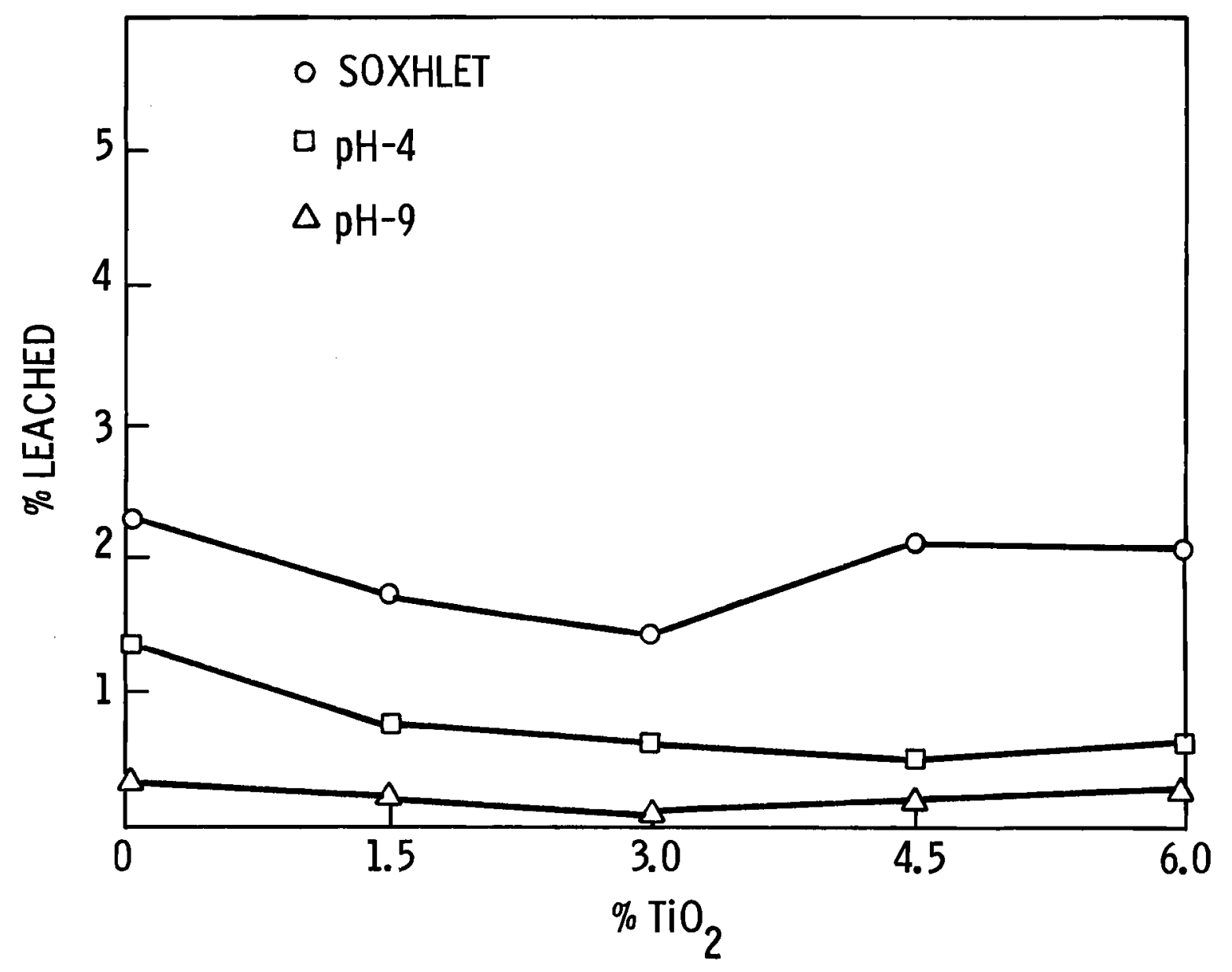

FIGURE 6. Leachability of 76-375 Type Glass with Change in $\mathrm{TiO}_{2}$ Content 


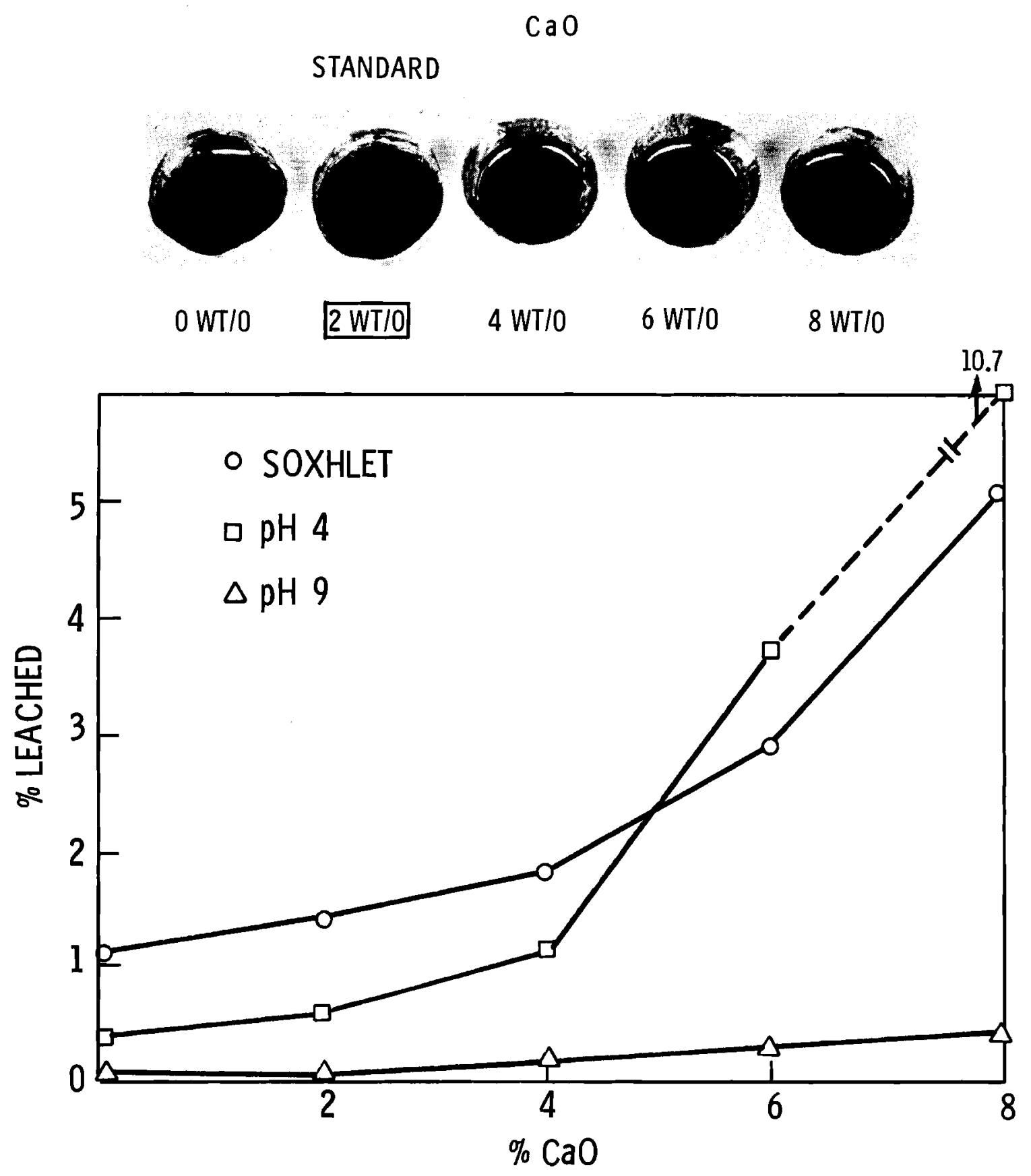

FIGURE 7. Leachability of 76-375 Type Glass with Change in $\mathrm{CaO}$ Content 

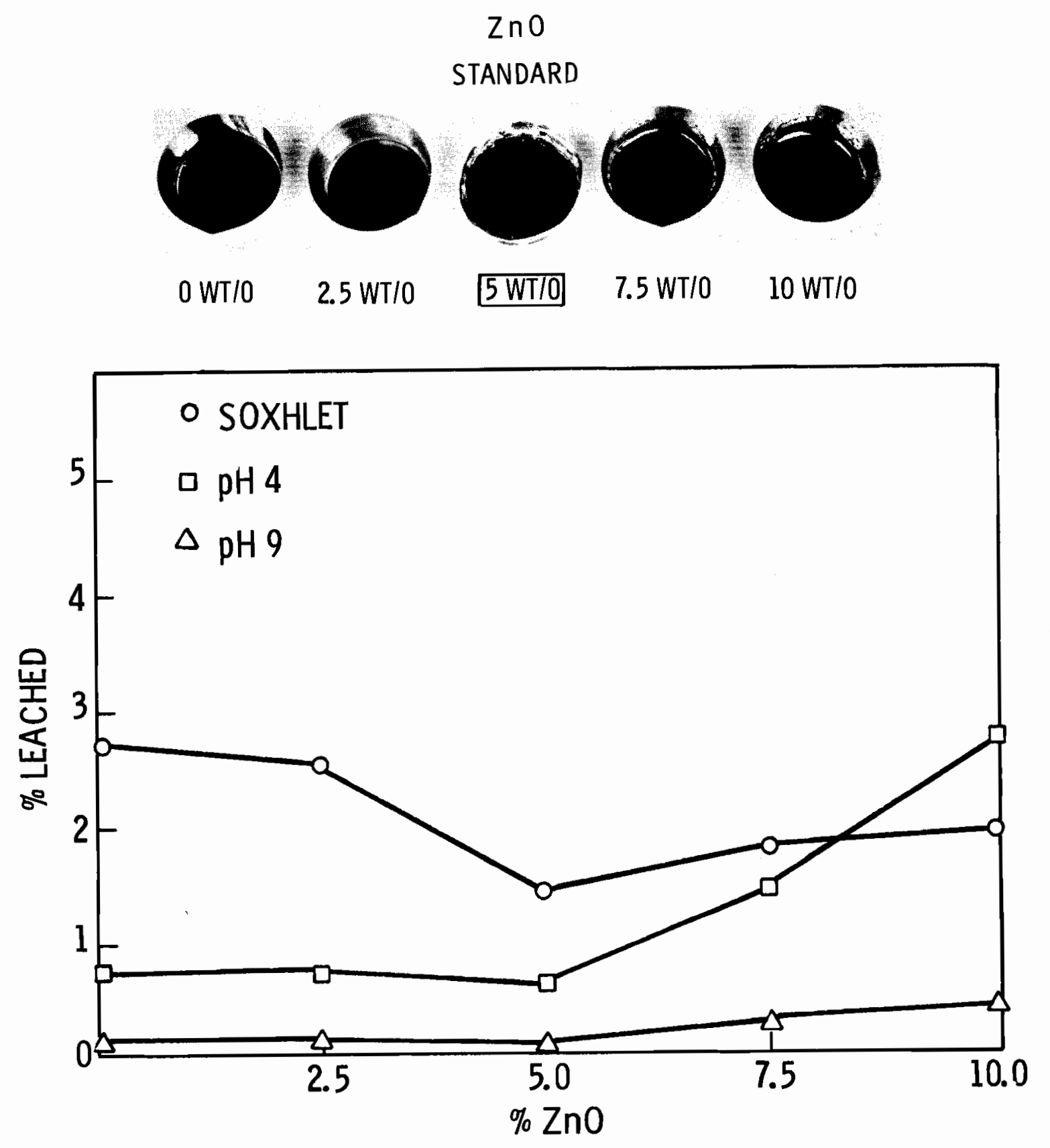

FIGURE 8. Leachability of 76-375 Type Glass with Change in Zno Content 
Soxhlet test), however, continues to decrease even at $21 \mathrm{wt} \% \mathrm{ZnO}$. The influence of the type of leach test on leach rate is one of the principal reasons that three leach tests were utilized for these tests. The $5 \mathrm{wt} \% \mathrm{ZnO}$ content has been chosen as a balance between the various leach requirements. $\mathrm{ZnO}$ does not appear to aid homogeneity in this waste glass, but it can generally be beneficial in aiding viscosity. Furthermore, high $\mathrm{ZnO}$ content readily forms a $\mathrm{Zn}_{2} \mathrm{SiO}_{4}$ crystal as a devitrification product, which is discussed in more detail in a separate report. ${ }^{(11)}$

For all of these reasons, it is apparent that the initialiy selected frit formulation is near optimum. Further tests have been made to determine the effectiveness of this type of formulation for processing requirements.

\section{VARIABILITY OF WASTE CONTENT}

Process design and instrumentation can provide close control of mixing ratios of waste and frit additives, but at times ratios may not be at the desired 2 frit to 1 waste oxide ratio. Tests have been run on different mixtures to determine how far the ratio can vary without causing major problems with the product. The effect of variations in waste content on leachability and viscosity, two of the most important parameters, is shown in Figure 9. Note that initial waste additions actually reduce both viscosity and leachability. Limits for in-can melting with this composition would be about 15 to $45 \mathrm{wt} \%$ waste. The ceramic melter for which this formulation was intended should not have a viscosity problem at the higher $1150^{\circ} \mathrm{C}$ temperature over 


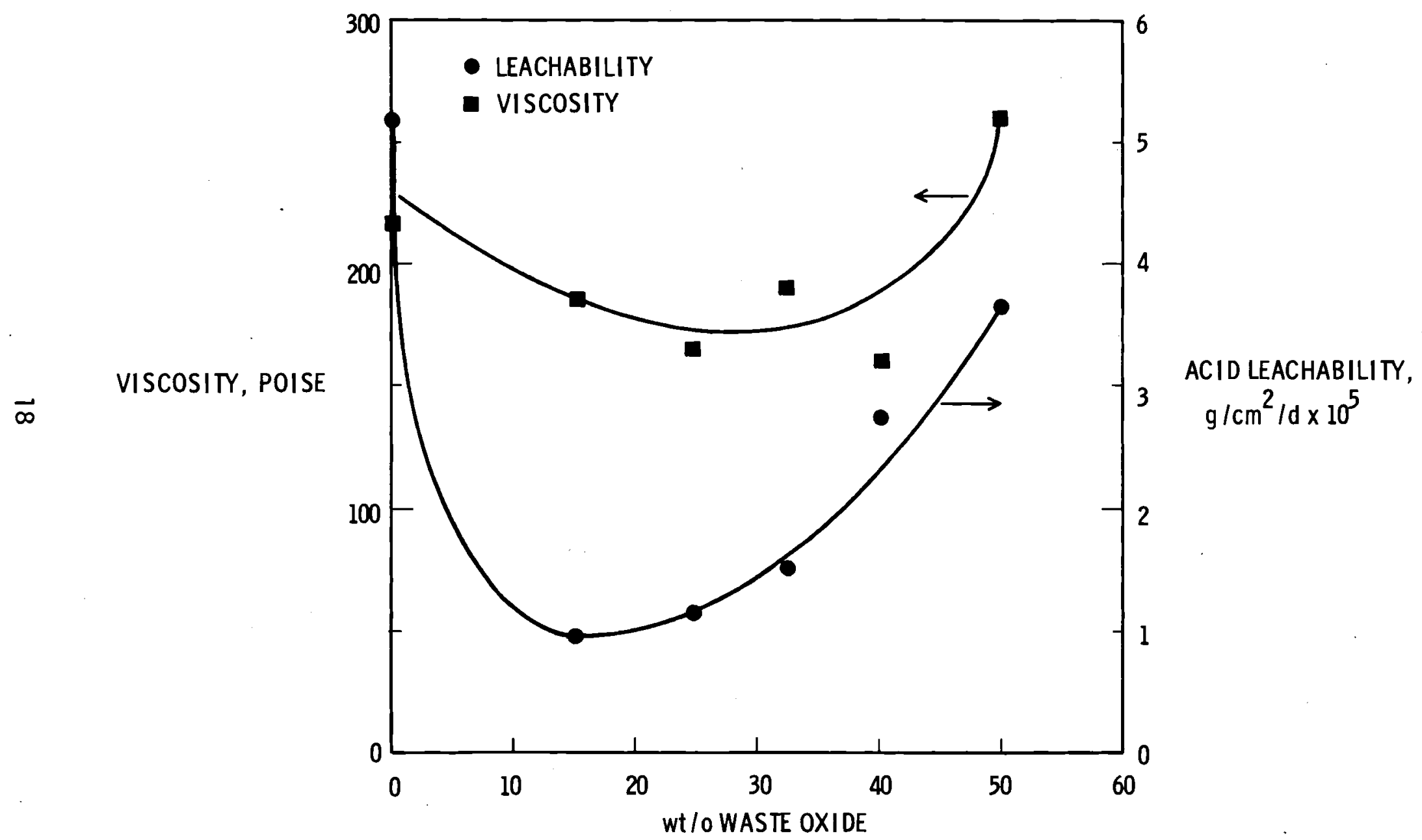

FIGURE 9. Effect of Waste Content on Viscosity at $1050^{\circ} \mathrm{C}$ and Acid Leachability as a Function of Waste 0xide Content 
the total range tested (0-50\% waste). However, the acid and soxhlet leachability are higher at the upper and lower limits of waste content, but would not be serious enough to require rework. These initial results indicate that there is a very wide range for acceptable frit-to-waste ratios; more detailed studies are planned to examine thermal and radiation effects.

SODIUM MOLYBDATE CONTROL

As discussed earlier, $\mathrm{Na}_{2} \mathrm{MoO}_{4}$ separation can be a problem with some waste types, and $\mathrm{B}_{2} \mathrm{O}_{3}$ can aid in controlling its behavior. However, additional methods of control are needed since separation may occur at high waste loadings even with higher $\mathrm{B}_{2} \mathrm{O}_{3}$ content. $\mathrm{Na}_{2} \mathrm{MoO}_{4}$ may also separate in cooler regions of process equipment since it has lower solubility in the melts at lower temperatures.

The chemical behavior of molybdenum can be controlled by reducing the high valence state $\left(\mathrm{MO}^{+6}\right)$ which causes its unique behavior. To reduce the valence of molybdate, reducing agents were added to the glass, e.g., silicon metal powder may react with the $\mathrm{Na}_{2} \mathrm{MoO}_{4}$ as indicated in the following equation:

$$
\begin{gathered}
\mathrm{Na}_{2} \mathrm{O}+2 \mathrm{Na}_{2} \mathrm{MoO}_{4}+3 \mathrm{Si} \rightarrow 3 \mathrm{Na}_{2} \mathrm{SiO}_{3}+2 \mathrm{Mo} \\
\Delta \mathrm{G}^{\circ} \approx-250 \mathrm{kcal}
\end{gathered}
$$


From standard free energies we calculated that the reaction has a large potential and so proceeds easily. Although the equation shows $\mathrm{Mo}^{+6}$ reduced completely to the metal, we have found that it is not necessary to reduce to that extent. Both laboratory and engineering scale tests have verified the effects of reducing agents on the glass behavior (a comparison of engineering scale canisters is shown in Figure 10). The absence of the yellow surface $\mathrm{Na}_{2} \mathrm{MoO}_{4}$ phase (arrow) can be noted. Also, unmelted material (principally $\mathrm{CeO}_{2}$ ) exists in the lower part of the canister (arrow). The reducing agents also appear to act on it to reduce it to $\mathrm{Ce}_{2} \mathrm{O}_{3}$ which is more soluble in the glass. Other oxides, such as ruthenium, rhodium, palladium, nickel and tellurium, are reduced to the metal state by addition of reducing agents. This is due to their lower free energy of formation compared to molybdenum, and they therefore exist as fine dispersed metallic crystals in the glass. Palladium and rhodium metal crystals have also been observed in nonreduced melts. Therefore, reducing agents have not created a new problem, but have increased the concentrations of insoluble metals in the glass. The overall effects appear very beneficial. 


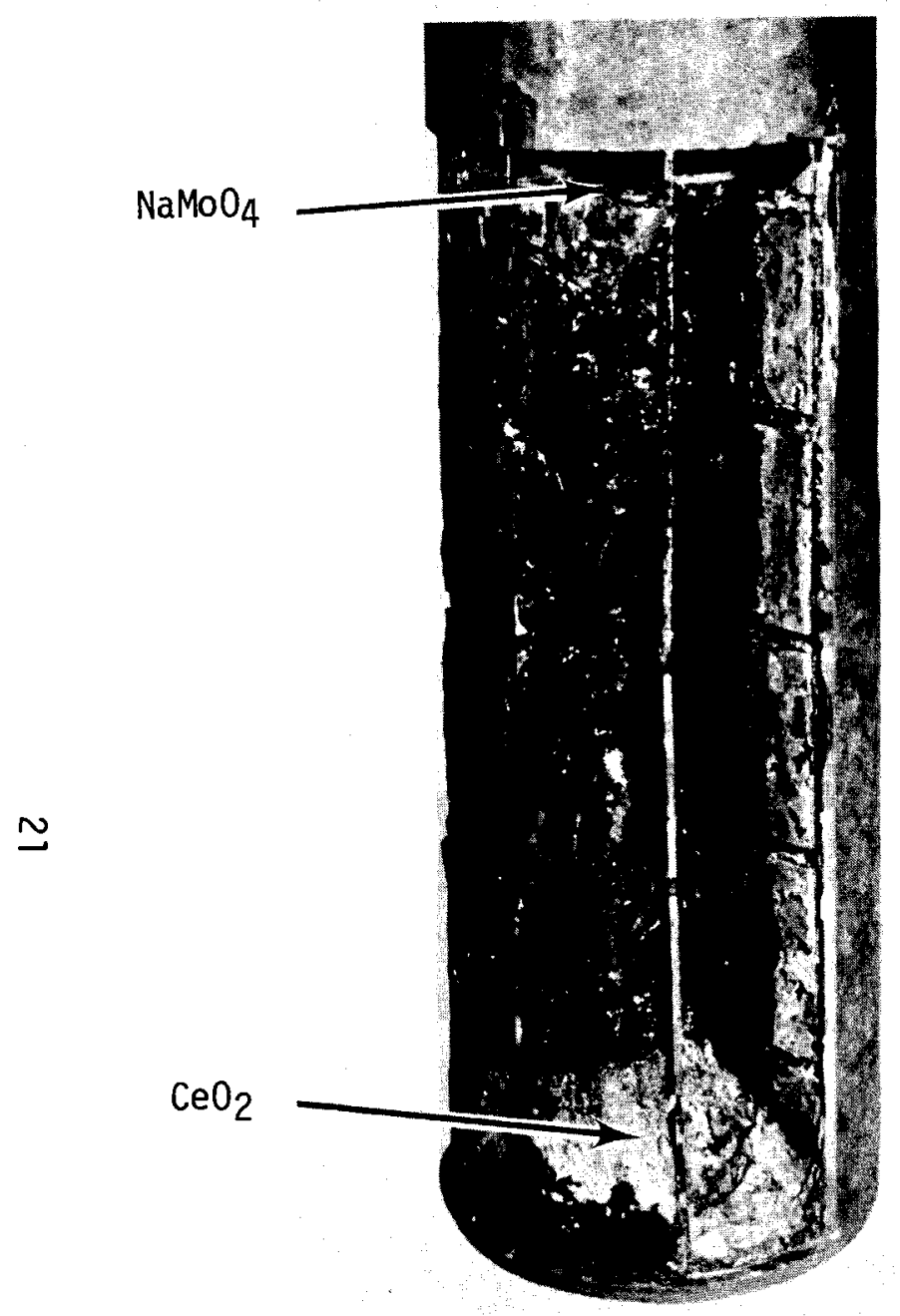

EARLY MELT SHOWING PHASE SEPARATIONS

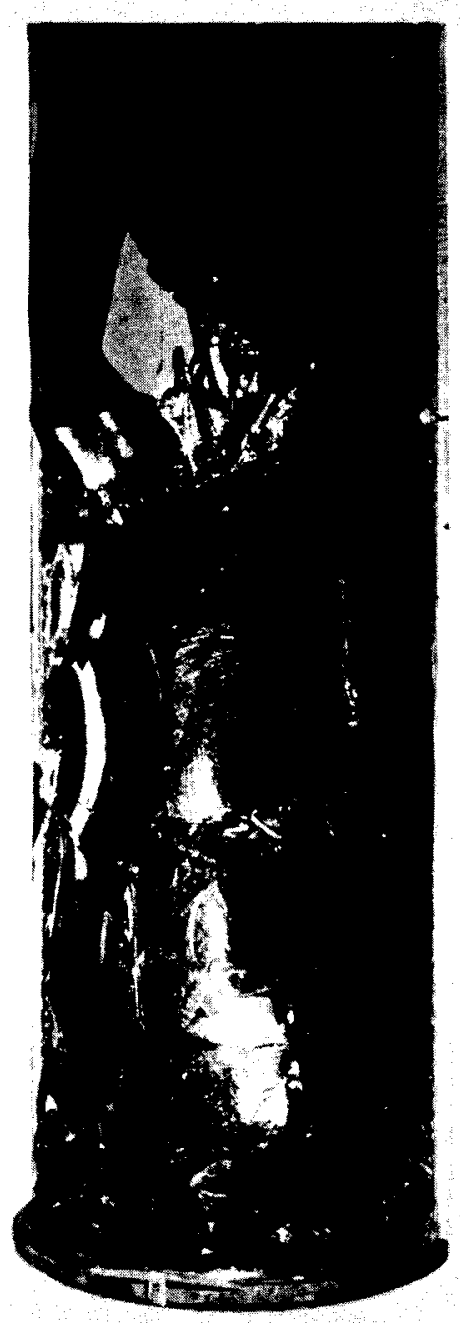

\section{RECENT MELT SHOWING REDUCTION OF PHASE SEPARATION}

FIGURE 10. Comparison of Engineering Scale Canisters Showing the Improvement in Homogeneity with Use of Reducing Agents 


\section{CONCLUSIONS}

In summary, the homogeneity and leach rates of waste glasses can be controlled by their composition. Since the two properties are generally competing, judgement is required in establishing the composition 1 imits for the glass additives.

- $\mathrm{Na}_{2} \mathrm{O}, \mathrm{K}_{2} \mathrm{O}$ and $\mathrm{CaO}$ have the greatest effect on homogeneity and leachability.

- Boric oxide additions and reducing agents are effective methods for sodium molybdate control.

- There are wide 1 imits on the ratio of frit to HLW oxide which can be incorporated in glasses without serious effect on important properties of viscosity and leach rate.

- The reference composition used in this test is near optimum for the composition ranges tested. 


\section{ACKNOWLEDGMENT}

Contributions to this study by J. C. Nelson and S. K. Jantz are gratefully acknowledged. 


\section{REFERENCES}

1. Ceramic and Glass Radioactive Waste Forms, CONF-770102, p. 2-81, January 1977.

2. G. B. Barton and J. A. Weed, Solidification of High Level Wastes, Part V, A Factorial Study of the Effect of Varying Concentration of the Components of Purex Type Waste on the Properties of Phosphate Solids, BNWL-544, Battelle, PNL, Richland, WA 99352, January 1968.

3. J. E. Mendel and J. L. McElroy, Waste Solidification Program, Volume 10, Evaluation of Solidified Waste Products, BNWL-1666, July 1972.

4. W. A. Ross, "Melt Development," Quarterly Progress Report, Research and Development Activities. Waste Fixation Program, Oct.-Dec. 1975, BNWL-1994, Apri1 1976, p. 2.1-2.8.

5. E. Ewest and H. W. Levi, Evaluation of Products for the Solidification of High-Level Radioactive Waste from Comercial Reprocessing in the Federal Republic of Germany, In: Management of Radioactive Wastes from the Nuclear Fuel Cycle, Vol. II, Proceedings of Symposium, Vienna, p. 22-26, March 1976. IAEA-SM-207/18, IAEA, Vienna, 1976.

6. F. Laude, et al., Confinement of Radioactivity in Glass, (Abstract in English, text in French.) IAEA-SM-207/36, IAEA, Vienna, 1976.

7. Properties of Phosphate and Silicate Glasses Used for the Solidification of Radioactive Waste, (Text and authors in Russian, abstract in English), IAEA-SM-207/109, Vienna, 1976.

8. J. E. Mendel et a1., Annual Report on the Characteristics of High-Level Waste Glasses. BNWL-2252, Battelle, Pacific Northwest Laboratories, Richland, WA 99352, June 1977 (pp 3-7).

9. H. T. Blair, Vitrification of Nuclear Waste Calcines by In-Can Melting. BNWL-2061, Battelle, Pacific Northwest Laboratories, Richland, WA 99352 , May 1976.

10. C. C. Chapman, Experience with a Joule-Heated Ceramic Melter While Converting Simulated High-level Waste to Glass. BNWL-2071, Battelle, Pacific Northwest Laboratories, Richland, WA 99352, August 1976.

11. J. E. Mende1, et a1., A Program Plan for Comprehensive Characterization of Solidified High-Level Wastes. BNWL-1940, Battelle, Pacific Northwest Laboratories, Richland, WA 99352, December 1975. 
,

$\because$ 
No. of

Copies

\section{UNITED STATES}

A. A. Churm

DOE Chicago Patent Group

9800 South Cass Avenue

Argonne, IL 60439

S. H. Smiley

Deputy Director for Fuels

and Materials

NRC Directorate of Licensing

for Fuels and Materials

4915 St. Elmo Ave.

Bethesda, MD 20014

W. P. Bishop

Chief, Waste Management Branch

NRC Division of Materials and

Fuel Cycle Facility Licensing

Washington, DC 20555

W. G. Belter

DOE Division of Biomedical and

Environmental Research

Earth Sciences Branch

Washington, DC 20545

W. A. Brobst

DOE Division of Environmental

Control Technology

Washington, DC 20545

W. E. Mott

DOE Division of Environmental Control Technology

Washington, DC 20545

G. W. Cunningham

Director, DOE Division of Waste Management, Production and

Reprocessing

Washington, DC 20545

R. B. Chitwood

DOE Division of Waste Management, Production and Reprocessing

Washington, DC 20545

C. R. Cooley

DOE Division of Waste Management, Production and Reprocessing

Washington, DC 20545

C. H. George

DOE Division of Waste Management,

Production and Reprocessing

Washington, DC 20545
No. of

Copies

C. A. Heath

DOE Division of Waste Management, Production and Reprocessing

Washington, DC 20545

G. Oertel

DOE Division of Waste Management, Production and Reprocessing

Washington, DC 20545

J. M. Taub

DOE Division of Waste Management, Production and Reprocessing Washington, DC 20545

D. L. Vieth

DOE Division of Waste Management, Production and Reprocessing Washington, DC 20545

R. D. Walton

DOE Division of Waste Management Production and Reprocessing Washington, DC 20545

DOE Idaho Operations Office

P. 0. Box 2108

Idaho Falls, ID 83401

J. J. Schreiber

DOE Oak Ridge Operations Office

P. 0. Box $X$

Oak Ridge, TN 37830

267 DOE Technical Information Center

A. P. Roeh, Manager

Process Evaluation Branch

Allied Chemical Corp.

550 - 2nd Street

Idaho Falls, Idaho 83401

J. B. Berreth

Allied Chemical Corporation

550 - 2nd Street

Idaho Falls, ID 83401

Allied Chemical Corporation

(File Copy)

550 - 2nd Street

Idaho Falls, ID 83401

J. A. Buckham

Allied-General Nuclear Services

P. 0. Box 847

Barnwel1, SC 29812 
No. of

Copies

A. Williams

Allied-General Nuclear Services

P.0. Box 847

Barnwel1, SC 29812

J. L. Jardine

M. J. Steindler/L. E. Trevorrow 2 Argonne National Laboratory 9700 South Cass Ave.

Argonne, IL 60439

Battelle Memorial Institute

505 King Ave.

Columbus, $\mathrm{OH} 43201$

2 Brookhaven National Laboratory Research Library

Reference Section

Information Division

Upton, Long Island, NY

Combustion Division

Combustion Engineering, Inc.

Windsor, CT 06095

2 M. A. Thompson

Rockwel1 International

Rocky Flats Division

Golden, C0 80401

M. D. Boersma

duPont Company, Aiken (DOE)

E. I. duPont DeNemours and Co. Savannah River Laboratory

Aiken, SC 29801

c. H. Ice

duPont Company, Aiken (DOE)

E. I. duPont DeNemours and Co.

Savannah River Laboratory

Aiken, SC 29801

A. S. Jennings

duPont Company, Aiken (DOE)

E. I. duPont DeNemours and Co.

Savannah River Laboratory

Aiken, SC 29801

P. H. Permar

duPont Company, Aiken (DOE)

E. I. duPont DeNemours and Co.

Savannah River Laboratory

Aiken, SC 29801

M. J. Plodinee

duPont Company, Aiken (DOE)

E. I. duPont DeNemours and Co.

Savannah River Laboratory

Aiken, SC 29801
No. of

Copies

L. Henning

Electric Power Research Institute

3412 Hillview Ave.

P.0. Box 10412

Palo Alto, CA 94304

Environmental Protection Agency

Technology Assessment Div. (AW-559)

Office of Radiation Programs

U.S. Environmental Protection Agency

Washington, DC 20460

R. G. Barnes

General Electric Company

175 Curtner Ave.

(M/C 160)

San Jose, CA 95125

L. H. Brooks

Gulf Energy and Environmental Systems

P. 0. Box 81608

San Diego, CA 92138

2 Central Research Library Document Reference Section

Oak Ridge National Laboratory (DOE)

Oak Ridge, TN 37830

3 Los Alamos Scientific Laboratory (DOE)

P. 0 . Box 1663

Los Alamos, NM 87544

C. J. Kershner

Monsanto Research Corporation

Mound Laboratory

P. 0. Box 32

Miamisburg, $\mathrm{OH} 45342$

John Pomeroy

Technical Secretary

National Academy of Sciences

Committee of Radioactive Waste Management

National Research Council

2101 Constitution Avenue

Washington, DC 20418

2 J. P. Duckworth

Plant Manager

Nuclear Fuel Services, Inc.

P.0. Box 124

West Valley, NY 14171 
No. of

Copies

J. G. Cline, General Manager NYS Atomic and Space Development Authority

230 Park Avenue, Rm. 2425

New York, NY 10017

J. K. Johnstone

Sandia Laboratories

Albuquerque, NM 87107

W. Weart

Division 1140

Sandia Laboratories

Albuquerque, NM 87107

H. D. Sivinski

Sandia Laboratories

Albuquerque, NM 87107

J. 0. Blomeke

Union Carbide Corporation (ORNL)

Chemical Technology Division

P. 0. Box Y

Oak Ridge, TN 37830

2 D. E. Ferguson

Union Carbide Corporation (ORNL) Chemical Technology Division

P. 0. Box $Y$

Oak Ridge, TN 37830

W. C. McClain

Union Carbide Corporation (ORNL)

Chemical Technology Division

P. 0. Box Y

Oak Ridge, TN 37830

7 C. D. Zerby

Union Carbide Corporation

Nuclear Division

Office of Waste Isolation

P.0. Box $Y$

Oak Ridge, TN 37830

R. A. Beall

U.S. Department of Interior

Bureau of Mines

Albany Research Center

1450 W. Queen Avenue

Albany, OR 97321

S. E. Logan

University of New Mexico

Albuquerque, NM 87131

R. G. Post

College of Engineering

University of Arizona

Tuscon, AZ 85721
No. of

Copies

Foreign

Rene Amavis

EURATOM

Health Physics Division

29, Rue Aldringer

Luxenbourge, BELGIUM

K. D. B. Johnson

Atomic Energy Research

Establishment

Harwe 11, Didcot,

Berks, ENGLAND

D. W. Clelland

United Kingdom Atomic Energy Authority

Risley, ENGLAND

P. J. Regnaut

Centre d'Etudes Nucleaires

de Fontenay-aux-Roses

Boite Postale 6

92 - Fontenay-aux-Roses

FRANCE

Y. J. Sousselier

Centre d'Etudes Nucleaires

de Fontenay-aux-Roses

Boite Postale 6

92 - Fontenay-aux-Roses

FRANCE

Bundesministerium für Forschung und Technologie

Stressemannstrasse 2

5300 Bonn

GERMANY

Hans W. Levi

Hahn-Meitner-Institut

für Kernforschung Berlin (HMI)

Glienicker Strasse 100

1000 Berlin 39

GERMANY

Center for Atomic Energy

Documentation (ZAED)

Attn: Dr. Mrs. Bel 1

P. 0. Box 3640

7500 Karlsruhe

GERMANY

H. Krause

Gesellschaft für

Kernforschung (GfK)

Postfach 3640

D7500 Karlsruhe GERMANY 
No. of

Copies

Ferruccio Gera

CNEN - C.S.N Casaccia

Laboratorio Rifiuti Radioacttivi

Casella Postale 2400

00100 Roma, ITALY

N. S. Sunder Rajan

Bhabha Atomic Research Center

Waste Treatment Division

Trombay, Bombay, 400085 INDIA

R. V. Amalraj

C.W.M.F. Project

P.0. Kalpakkam

Chingleput Dist.

Tami 1 Nadu, INDIA

2 International Atomic Energy

Agency

Kärtner Ring 11

P.0. Box 590

A-1011, Vienna, AUSTRIA

M. Tomlinson

Director of Chemistry and

Materials Science Division

Atomic Energy of Canada Ltd.

Whiteshell Nuclear Research

Establ ishment

Pinawa, Manitoba, CANADA

ONSITE - RICHLAND, WA 99352

5 DOE Richland Operations Office

R. B. Goranson

M. J. Shupe

D. J. Squires

M. J. Zamorski

H. E. Ransom

10 Rockwell Hanford Operations
H. Babad
L. C. Chick
R. A. Deju
R. J. Gimera
E. J. Kosiancic
M. J. Kupfer
C. M. Manry
J. H. Roecker
D. D. Widrich
File Copy

Exxon

S. J. Beard

Joint Center for Graduate Study

J. Cooper
No. of

Copies

2 United Nuclear Insdustries, Inc.

T. E. Dabrowski

A. E. Engler

Westinghouse Hanford Company

A. G. Blasewitz

Battelle-Northwest

J. W. Bartlett

W. J. Bjorklund

H. T. Blair

W. F. Bonner

D. J. Bradley

J. L. Buelt

L. R. Bunnel1

C. C. Chapman

T. D. Chikalla

A. A. Garrett

E. R. Irish

J. H. Jarrett

Y. B. Katayama

D. E. Larson

J. M. Lukacs

R. P. Marsha11

J. L. McElroy

G. B. Mellinger

J. E. Mendel

W. J. Mikols

R. E. Nightingale

D. E Olesen

A. M. Platt

D. L. Prezbindowski (2)

F. P. Roberts

W. A. Ross (15)

J. M. Rusin

D. H. Siemens

R. P. Turcotte

H. H. Van Tuyl

J. H. Westsik, Jr.

L. D. Williams

Technical Information (5)

Technical Publications 


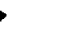

